\section{Preliminary Evaluation of Apple Germplasm from Kazakhstan for Resistance to Postharvest Blue Mold in Fruit Caused by Penicillium expansum}

\author{
Wojciech J. Janisiewicz ${ }^{1}$ \\ Appalachian Fruit Research Station, Agricultural Research Service, U.S. \\ Department of Agriculture, 2217 Wiltshire Road, Kearneysville, WV 25430
}

Robert A. Saftner and William S. Conway

Produce Quality and Safety Laboratory, Henry A. Wallace Beltsville Agricultural Research Center, Agricultural Research Service, U.S. Department of Agriculture, Beltsville, MD 20705

\section{Philip L. Forsline}

Plant Genetic Resources Unit, Agricultural Research Service, U.S. Department of Agriculture, Geneva, NY 14456

Additional index words. postharvest decay, apple resistance, Malus

\begin{abstract}
Blue mold of apples, incited by Penicillium expansum, causes extensive losses on stored apples worldwide. Despite the severity of this problem, apple breeders do not evaluate their crosses for resistance to this disease, because there has been little resistance to blue mold in the gene pool of the germplasm used. A new apple germplasm collection from the center of origin in Kazakhstan, maintained in Geneva, NY, and representing a much broader gene pool, was evaluated for resistance to blue mold. Apples were harvested from the Elite collection trees that were clonally propagated from budwood collected in Kazakhstan and from seedling trees originating from seeds of the same trees as the Elite budwood or from other wild seedling trees in Kazakhstan. Fruit from 83 such accessions were harvested at the preclimacteric to climacteric stage, wound-inoculated with $P$. expansum at $10^{3}, 10^{4}$, and $10^{5} \mathrm{~mL}^{-1}$ conidial suspension, incubated for $5 \mathrm{~d}$ at $24^{\circ} \mathrm{C}$, and evaluated for decay incidence and severity. Two accessions were classified as immune (no decay at $10^{3}$ and $10^{4} \mathrm{~mL}^{-1}$ ), four as resistant (no decay at $10^{3} \mathrm{~mL}^{-1}$ ), 53 as moderately resistant (lesions less than $10 \mathrm{~mm}$ at $10^{3} \mathrm{~mL}^{-1}$ ), and 24 as susceptible. There were positive correlations $(r=0.92,0.86$, and 0.91$)$ between decay severity and all three inoculum levels. Our results indicate a greater genetic diversity among the Kazak apple collection than among cultivated apples as evidenced by their broad range of fruit maturity, quality, and disease resistance patterns. The immune and resistant accessions may serve as a source of resistance in breeding programs and can be useful in explaining the mechanism of resistance to blue mold in apples.
\end{abstract}

Apple is one of the most important species among the temperate fruit crops. According to Vavilov (1930), Central Asia is the center of origin for the domestic apple. His theory of "geography of genes," that germplasm for breeding for resistance should be obtained from the plant's geographical origin, is assuming particular significance now as natural habitats are quickly being eliminated (Dzhangaliev, 2003; Forsline et al., 2003; Vavilov, 1927). Wild forest stands of Malus sieversii with a great diversity of fruit with respect to a range of forms, colors, and tastes

Received for publication 23 July 2007. Accepted for publication 10 Oct. 2007.

We thank Dr. Dariusz Swietlik for suggesting this study, Willard Douglas and Eunhee Park for technical assistance with the maturity evaluation, and Roger Lewis for summarizing decay data and making graphs.

${ }^{1}$ To whom reprint requests should be addressed; e-mailwojciech.janisiewicz@ars.usda.gov
In a survey of the New York market from 1972 to 1984, blue mold caused by Penicillium expansum was the most damaging parasitic postharvest disease of apple (Cappellini et al., 1987). Attempts to document losses from this and other postharvest diseases of apple have mainly emphasized the fate of apple fruit in large storages, in transit, or in markets where they are sold (Cappellini et al., 1987; Spotts et al., 1999). In contrast, little information is available on the very significant losses that occur in restaurants and private homes. For decades, the lack of such data has led scientists and administrators to underestimate the importance of postharvest diseases (Kelman, 1984). However, as pathogens such as $P$. expansum or Botrytis cinerea (Lennox and Spotts, 2003) develop resistance to fungicides and regulatory agencies place more restrictions on the use of fungicides after harvest (Gullino and Kuijpers, 1994; Ragsdale and Sisler, 1994), postharvest losses of various fruits, including apple, are increasing and greater emphasis is being directed at postharvest diseases (Narayanasamy, 2006; Rosenberger, 1999). Future postharvest use of fungicides is in question because many countries already have either completely banned or severely restricted postharvest applications of fungicides (Gullino and Kuijpers, 1994). Various alternatives to synthetic fungicides have been developed during the past decade for protecting pome fruits against postharvest decays, including biological control, sanitation, various physical treatments (e.g., heat, ultraviolet), or the use of substances generally regarded as safe (GRAS) (Janisiewicz and Korsten, 2002; Lurie, 1998; Watkins et al., 2004; Wilson et al., 1994). Biological control, using bacteria or yeasts that naturally colonize fruit, have shown much promise and is used on a commercial scale in the United States against blue mold and gray mold of pome fruits (e.g., Bio-Save; JET Harvest Solutions, Orlando, FL). However, even the most promising alternatives do not have as broad spectrum of activity as fungicides and cannot be used under as many different conditions. Many of these alternatives are much more effective on less mature apples, which are more resistant to decay than mature ripening fruit (W.J. Janisiewicz, unpublished data). Even a slight improvement in fruit resistance to decay could increase the effectiveness of these alternatives and result in an additive or even synergistic effect. Efforts have been made to combine various components, including resistance breeding, to effectively control insects and diseases on apples. However, this search for alternative control strategies that combines various approaches under the integrated pest management concept has had its primary focus on apple field production (Hogmire, 1995). There are no reports comparing resistance of collections of apple germplasm with $P$. expansum or any other postharvest disease, and breeders generally do not systematically screen for resistance to postharvest decays when evaluating their crosses (R.L. Bell, personal communication). 
Observations of resistance to fruit decays are limited because breeders generally want to evaluate noninfected fruit for fruit quality and yield. This may reflect the general belief that little resistance or variation in resistance against postharvest decays exists in the gene pool currently used in breeding programs, the lack of awareness of the significant losses caused by postharvest decays, or the belief that fungicides can take care of the problem. The few reports on the variability of resistance in apple cultivars to postharvest decays indicate some differences in susceptibility but relatively little on actual resistance to decay (Cappellini et al., 1987; Janisiewicz and Peterson, 2004; Spotts et al., 1999). These reports are mostly descriptive in nature, and when the research was done, the experiments were mostly limited to a single variable (e.g., one inoculum level) or to other specific conditions that limited the interpretation of the results.

The objective of this study was to characterize disease resistance to postharvest blue mold decay among apples from the Kazakhstan germplasm (Kazak) collection. This may lead to the utilization of any identified highresistance germplasm in apple breeding programs using traditional or genetic engineering approaches. We report on a preliminary evaluation of accessions of original clones and seedlings originating from seeds collected in Kazakhstan.

\section{Materials and Methods}

Fruit. The Kazak apple germplasm collection is maintained at the USDA-ARS, Plant Germplasm Resource Unit at Cornell University, New York State Agricultural Experiment Station, Geneva, NY. Apples were harvested from the Elite (clonally propagated from budwood collected from trees in Kazakhstan) collection trees (identified by PI number) and from seedling trees originating from open-pollinated seeds of the same trees as the Elite budwood or from different trees in Kazakhstan [identified by Geneva Malus (GMAL) number with a letter extension] (Table 1). The Elite collection had two 5-year-old trees for each accession. The two trees of each accession were planted next to each other $3.7 \mathrm{~m}$ apart in the row, and the tree rows were $6.1 \mathrm{~m}$ apart. Each seedling was an individual 7-year-old tree on its own root system planted in a sstaggered pattern in double rows with trees $1.5 \mathrm{~m}$ apart within the row and $1.8 \mathrm{~m}$ between the rows. Double rows were planted $3.7 \mathrm{~m}$ apart. For many accessions, the projected dates of harvest were established based on bloom time and a visual observation of changes in fruit appearance in previous years. The projected dates of harvest ranged from 7 Aug. through the end of September with the majority maturing in the latter part of August and the first half of September. There were also three accessions harvested in early October.

For our experiments, fruit were harvested on 8 to 9 Aug. and 21 to 22 Aug. and 7 Sept. and 26 to 27 Sept. Harvested apples were placed in $4{ }^{\circ} \mathrm{C}$ storage overnight, transported to the ARS Appalachian Fruit Research Station (AFRS) in Kearneysville, WV, the next day, and placed in overnight storage at $4{ }^{\circ} \mathrm{C}$. On the second day after harvest, fruit were randomly selected from each accession for inoculation at AFRS and for transportation to the ARS Beltsville Agricultural Research Center in Beltsville, MD, for maturity evaluation.

The size of the apples collected from the Elite trees was generally larger than those from the seedlings. This is mainly because of their genetic potential (selected as elites in the apple forests partly because of superior size) and growth conditions because seedling trees were growing densely packed in double rows with intermingling crowns from neighboring trees. The descriptor record when collected can be found at the web site $<$ http:// www.ars-grin.gov/cgi-bin/npgs/html/search.pl> by entering the PI number for elites and GMAL number for seedlings to search the observation record that includes fruit size. The information about GMAL 3622.h, for example, can be found by searching GMAL 3622 , which will show the original data observed on the mother tree GMAL 3622 ; GMAL 3622.h is one of the progenies of the mother tree from which seeds were harvested in the Kazakhstan forest.

Assessment of fruit maturity and quality indices. Before the first harvest, fruit from all accessions designated for harvest on 8 to 9 Aug. were tested for starch content using the iodine test and the 1-9 scale developed for 'Golden Delicious' (Smith et al., 1979). Only fruit with a starch index above 3 were harvested. When available, at least 80 fruit per accession were harvested. However, it quickly became apparent that the maturation of apples from the seedlings often did not follow the classical starch hydrolysis pattern during fruit maturation. Some seedling fruit with a high starch content were dropping from the trees, whereas others with low starch were still preclimacteric and still others with high starch were already postclimacteric. Because the starch index was not a good indicator of harvest maturity in seedling accessions, starch analyses of seedling fruit were eventually discontinued, and only fruit from the Elite collection were harvested based on the starch index.

Maturity of the fruit at the time of decay analyses was determined in the Produce Quality and Safety Laboratory ARS, Beltsville, MD. For each accession, the respiration, as indicated by evolved $\mathrm{CO}_{2}$, and ethylene production rates of one two- to eight-fruit sample $(\approx 200 \mathrm{~g})$ were measured every $6 \mathrm{~h}$ during a 5 - to $7-\mathrm{d}$ period at $20^{\circ} \mathrm{C}$ using an automated flow-through system (Izumi et al., 1996). Carbon dioxide evolution and ethylene production are reported as $\mathrm{nmol} \cdot \mathrm{kg}^{-1} \mathrm{~s}^{-1}$ and $\mathrm{pmol} \cdot \mathrm{kg}^{-1} \cdot \mathrm{s}^{-1}$, respectively. Apple accessions were classified into three maturity stages: preclimacteric $=$ fruit samples producing less than $2 \mathrm{pmol} \cdot \mathrm{kg}^{-1} \cdot \mathrm{s}^{-1}$ ethylene; climacteric $=$ fruit samples showing an increasing rate of ethylene production with time, i.e., one or more, but not necessarily all, fruit in the sample are in the climacteric stage of development; and postclimacteric $=$ fruit samples showing an decreasing rate of ethylene production with time, i.e., one or more, but not necessarily all, fruit in the sample are in the postclimacteric stage of development.

Soluble solids content (SS) and titratable acidity (TA) were measured on juice extracts of three- to eight-fruit samples from each accession. Fruit samples were macerated in an electric blender and the juice separated from the pulp by squeezing through two layers of cheesecloth. Soluble solids content of juice samples was measured using a digital, temperature-compensated refractometer (model PR-101; Atago Co., Tokyo) and TA, expressed as malic acid, was determined by titrating $10-\mathrm{mL}$ juice samples with $1.0 \mathrm{M}$ $\mathrm{KOH}$ to pH 8.2 (Mitcham and Kader, 1996). For comparison, 'Golden Delicious' apples harvested 135 to $150 \mathrm{~d}$ from full bloom have an average starch staining score of 4 to 5 , respiration and ethylene production rates of 50 to $180 \mathrm{nmol} \cdot \mathrm{kg}^{-1} \cdot \mathrm{s}^{-1}$, and 10 to 1700 $\mathrm{pmol} \cdot \mathrm{kg}^{-1} \cdot \mathrm{s}^{-1}$, respectively, at $20^{\circ} \mathrm{C}$ in air and SS content between $11 \%$ and $15 \%$ (Mitcham et al., 2007; Saftner et al., 2003).

Pathogen. The $P$. expansum isolate (MD8 ) used in this study is an aggressive pathogen isolated from a decayed apple. The pathogen was grown on potato dextrose agar and virulence was maintained by periodic transfers through apple fruit. Aqueous suspensions of the pathogen conidia at $1 \times 10^{3}$, $1 \times 10^{4}$, and $1 \times 10^{5} \mathrm{~mL}^{-1}$ used for fruit inoculation were prepared from a 10-d-old culture as previously described (Janisiewicz and Marchi, 1992).

Inoculation study. The apples from cold storage were placed on fruitpack trays in plastic boxes and incubated overnight at $24{ }^{\circ} \mathrm{C}$ before inoculating with $P$. expansum. The goal was to inoculate 63 apples for each accession, 21 apples for each of three concentrations of the pathogen. However, in many cases, the number of available fruit was smaller. The actual number of fruit tested for each accession is indicated in Table 1. Because $P$. expansum can infect apple successfully only through wounds, each apple was wounded at the equator to a depth of 3 $\mathrm{mm}$ with a 6-penny nail that simulates a stem puncture wound frequently occurring in bins filled with apples. Apples were wound inoculated with $50 \mu \mathrm{L}$ per wound of conidial suspension $\left(1 \times 10^{3}, 1 \times 10^{4}\right.$, or $\left.1 \times 10^{5} \mathrm{~mL}^{-1}\right)$ of $P$. expansum using our standard inoculation procedure (Janisiewicz et al., 2003). The inoculated fruit were incubated at $22 \pm 2{ }^{\circ} \mathrm{C}$ for $5 \mathrm{~d}$ and then evaluated for decay development by measuring the diameter of the decayed lesions. In addition, fruit from each accession was photographed to record different decay patterns among apple accessions. The photographs for individual accessions are available for viewing at $<\mathrm{http} / / \mathrm{www}$. ars.usda.gov/pandp/docs.htm?docid=15137>. Standard deviations were calculated for severity of decay and the accessions were divided into four resistance categories: 
Table 1. Resistance levels to blue mold of apples from the Kazak collection of Elite (PI) and seedlings (GMAL) wound inoculated with various concentrations of Penicillium expansum conidia and incubated for $5 \mathrm{~d}$ in air at $22{ }^{\circ} \mathrm{C}$.

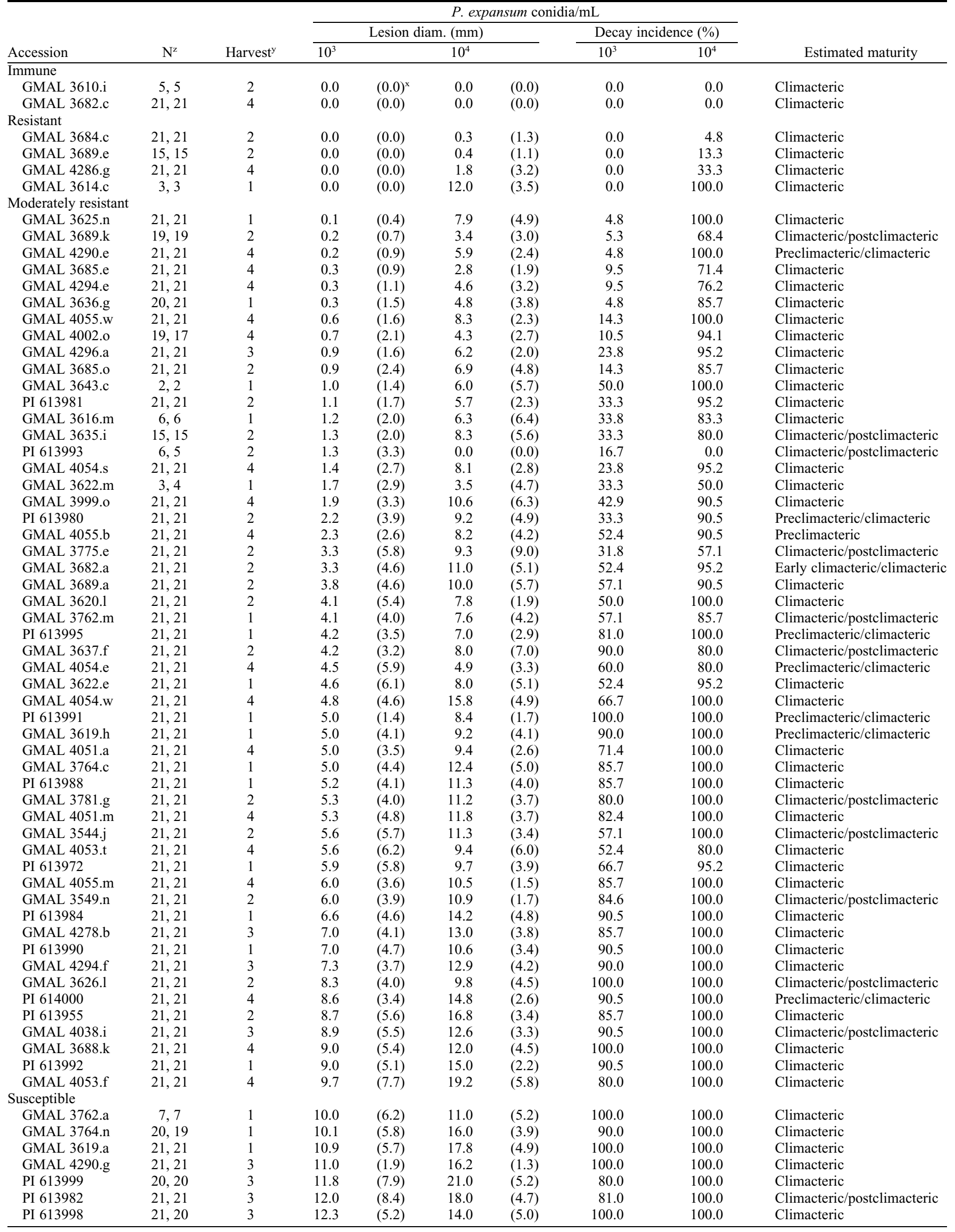


Table 1. (Continued) Resistance levels to blue mold of apples from the Kazak collection of Elite (PI) and seedlings (GMAL) wound inoculated with various concentrations of Penicillium expansum conidia and incubated for $5 \mathrm{~d}$ in air at $22{ }^{\circ} \mathrm{C}$.

\begin{tabular}{|c|c|c|c|c|c|c|c|c|c|}
\hline \multirow{2}{*}{ Accession } & \multirow{2}{*}{$\mathrm{N}^{\mathrm{z}}$} & \multirow{2}{*}{ Harvest $^{\mathrm{y}}$} & \multicolumn{6}{|c|}{ P. expansum conidia $/ \mathrm{mL}$} & \multirow{2}{*}{ Estimated maturity } \\
\hline & & & \multicolumn{4}{|c|}{ Lesion diam. $(\mathrm{mm})$} & \multicolumn{2}{|c|}{ Decay incidence (\%) } & \\
\hline GMAL 3622.h & 4,3 & 1 & 13.0 & $(5.4)$ & 20.0 & $(4.6)$ & 100.0 & 100.0 & Climacteric/postclimacteric \\
\hline PI 613983 & 23,23 & 2 & 13.3 & $(5.2)$ & 15.1 & $(5.5)$ & 100.0 & 100.0 & Climacteric/postclimacteric \\
\hline PI 613971 & 21,21 & 2 & 13.4 & (7.3) & 17.4 & (4.9) & 90.5 & 100.0 & Climacteric \\
\hline PI 613989 & 20,20 & 2 & 14.4 & (4.1) & 17.9 & $(2.7)$ & 100.0 & 100.0 & Climacteric/postclimacterio \\
\hline PI 613973 & 7,7 & 1 & 14.7 & (4.1) & 15.7 & (4.4) & 100.0 & 100.0 & Climacteric \\
\hline PI 613977 & 15,15 & 2 & 17.0 & $(3.1)$ & 20.5 & (3.2) & 100.0 & 100.0 & Climacteric \\
\hline PI 613987 & 21,20 & 1 & 17.8 & (3.3) & 20.9 & $(2.0)$ & 100.0 & 100.0 & Climacteric \\
\hline PI 632626 & 7,7 & 1 & 17.9 & (2.7) & 21.0 & (1.7) & 100.0 & 100.0 & Climacteric \\
\hline GMAL 3622.1 & 5,5 & 1 & 18.4 & (2.7) & 23.4 & (1.7) & 100.0 & 100.0 & Climacteric \\
\hline PI 613956 & 20,19 & 3 & 19.2 & (3.4) & 23.4 & (1.5) & 100.0 & 100.0 & Climacteric/postclimacteric \\
\hline PI 613994 & 5,5 & 1 & 19.2 & (2.9) & 20.0 & $(5.5)$ & 100.0 & 100.0 & Climacteric \\
\hline PI 613974 & 21,21 & 2 & 19.6 & $(3.2)$ & 22.4 & $(2.1)$ & 100.0 & 100.0 & Climacteric/postclimacterio \\
\hline
\end{tabular}

${ }^{2}$ Number of fruit inoculated with $P$. expansum conidial suspensions of $10^{3}$ and $10^{4} \mathrm{~mL}^{-1}$.

${ }^{\mathrm{y}}$ Date of harvest: $1=8-9$ Aug., $2=21-22$ Aug., 3 = 7 Sept., $4=26-27$ Sept.

${ }^{\mathrm{x}}$ Standard error of the means.

immune $=$ no decay at inoculum levels of $1 \times$ $10^{3}$ and $1 \times 10^{4} \mathrm{~mL}^{-1}$; resistant $=$ no decay at 1 $\times 10^{3} \mathrm{~mL}^{-1}$; moderately resistant $=$ decay lesion diameter less than $10 \mathrm{~mm}$ at $1 \times 10^{3}$ $\mathrm{mL}^{-1}$; and susceptible $=$ decay lesion diameter greater than $10 \mathrm{~mm}$ at $1 \times 10^{3} \mathrm{~mL}^{-1}$.

\section{Results and Discussion}

Decay development. A total of 83 accessions from the four harvest dates were evaluated for decay development (Table 1) and maturity (Table 2) between 2 and $8 \mathrm{~d}$ after harvest. Of the 83 accessions, two showed no lesions on fruit inoculated with $P$. expansum conidial suspensions of $1 \times 10^{3}$ and $1 \times 10^{4}$ $\mathrm{mL}^{-1}$; these were classified as immune. Four other accessions had no lesion development when wound-inoculated with the $1 \times 10^{3}$ $\mathrm{mL}^{-1}$ conidial suspension, and these were classified as resistant. Fifty-three accessions had lesions less than $10 \mathrm{~mm}$ in diameter after wound inoculation with a $1 \times 10^{3} \mathrm{~mL}^{-1}$ conidial suspension, and these were classified as moderately resistant. The remaining 24 accessions were categorized as susceptible, having lesion diameters greater than $>10 \mathrm{~mm}$ after the same low-dosage pathogen treatment. However, accessions GMAL 3610.i and GMAL 3682.c, classified as immune, were not totally immune because they developed lesions $7.8 \mathrm{~mm}$ and $2.7 \mathrm{~mm}$ in diameter and had an incidence of decay of $100 \%$ and $70 \%$, respectively, on fruit inoculated with a $1 \times 10^{5} \mathrm{~mL}^{-1}$ conidial suspension (data not shown). Also, only five fruits were tested for GMAL 3610.i at the two lower concentrations of the inoculum, and at the lowest inoculum level, leathery, mostly superficial browning atypical of blue mold, developed on four fruits around the wounded area.

Apple is a climacteric fruit, exhibiting increased respiration and ethylene production rates during maturation and ripening (Saltveit, 2004). During fruit enlargement and maturation, respiration declines to a preclimacteric minimum. With the onset of ripening, apples undergo a climacteric rise, a climacteric peak, and a postclimacteric decline in respiration and a corresponding pattern of increase and decrease in autocatalytic ethylene production.

Noninoculated fruit of both immune accessions and the four resistant accessions were in the climacteric stage of development at the time corresponding to inoculation and during the time of decay development (Table 2). Immune accession GMAL 3682.c had a relatively low respiration rate compared with other accessions even as ethylene production rates increased more than 10 -fold during the period when inoculated fruit were being incubated. The starch level of these fruit was 6.5 according to a 9-point scale for 'Golden Delicious', further confirming their advanced stage of maturity. Resistant accessions, GMAL 3684.c and GMAL 4289.e, developed only a few small lesions after inoculation with $P$. expansum conidial suspensions of $1 \times 10^{4} \mathrm{~mL}^{-1}$. GMAL 3684.c had only $4.8 \%$ of the wounds infected and the fruit were in the climacteric stage during experimentation. Interestingly, this accession was resistant despite having a relatively high SS (14.1) level (Table 2). The immune GMAL 3682.c and resistant GMAL 3684.c, GMAL 4289.e, and GMAL 4286.g accessions were tested with a large number of fruit, giving additional confidence to the results on decay development (Table 1).

Most of the accessions fell into the moderately resistant category. Only five of them had less than $80 \%$ decayed fruit after inoculation with a $1 \times 10^{4} \mathrm{~mL}^{-1}$ conidial suspension; GMAL3775.e had only $57 \%$ of the fruit infected, whereas most other accessions in this category had $100 \%$ decayed fruit. PI 613993 had no infection at this inoculum level, but only five fruit were inoculated. Both accessions were at the climacteric stage at the time of inoculation and advanced to the postclimacteric stage. Many accessions had small lesions, but the incidence of decay was high. Among susceptible accessions, at the $1 \times 10^{3} \mathrm{~mL}^{-1}$ conidial inoculum level, only five accessions had less than $100 \%$ fruit infected and their infection rate was at or above $80 \%$. All susceptible accessions except one inoculated with $1 \times 10^{4} \mathrm{~mL}^{-1}$ inoculum level had $100 \%$ fruit infected. Additional information on decay development that includes fruit inoculated with a $1 \times 10^{5} \mathrm{~mL}^{-1}$ conidial suspension after the 6-d incubation period can be accessed at $<\mathrm{http}: / /$ www.ars. usda.gov/pandp/docs.htm?docid=15137>.

Fruit maturity. Respiration and especially ethylene production rates have been widely used over the years as indicators of harvest maturity. In some cases, starch hydrolysis and background skin color are also considered important harvest maturity indices. Maturity and quality indices for optimal harvest period for each apple variety may vary widely for different geographic regions. For best storage performance, fruit of some apple varieties are harvested well before autocatalytic ethylene production, whereas fruit of other cultivars are harvested during the early climacteric stage of development. However, ethylene production is still regarded as the only physiological indicator of apple fruit maturity and as fruit mature, they become more susceptible to infection by pathogens (Kader, 1985). Maturity data revealed a wide range of maturation patterns (Table 2; also, for more details, see <http://www.ars.usda.gov/ pandp/docs.htm?docid=15137>).

In general, fruit of early-season genotypes (summer apples) have high climacteric respiration and ethylene production rates and ripen quickly, whereas late-season genotypes (fall apples) have generally lower respiration and ethylene production rates and ripen more slowly (Watkins et al., 2004). Likewise, many of the earlier maturing apples from the Kazak collection exhibited higher and more pronounced increases in respiration and ethylene production rates than later 
Table 2. Maturity or quality indices of apples from the Kazak collection Elite (PI) and seedlings (GMAL) evaluated for susceptibility to blue mold.

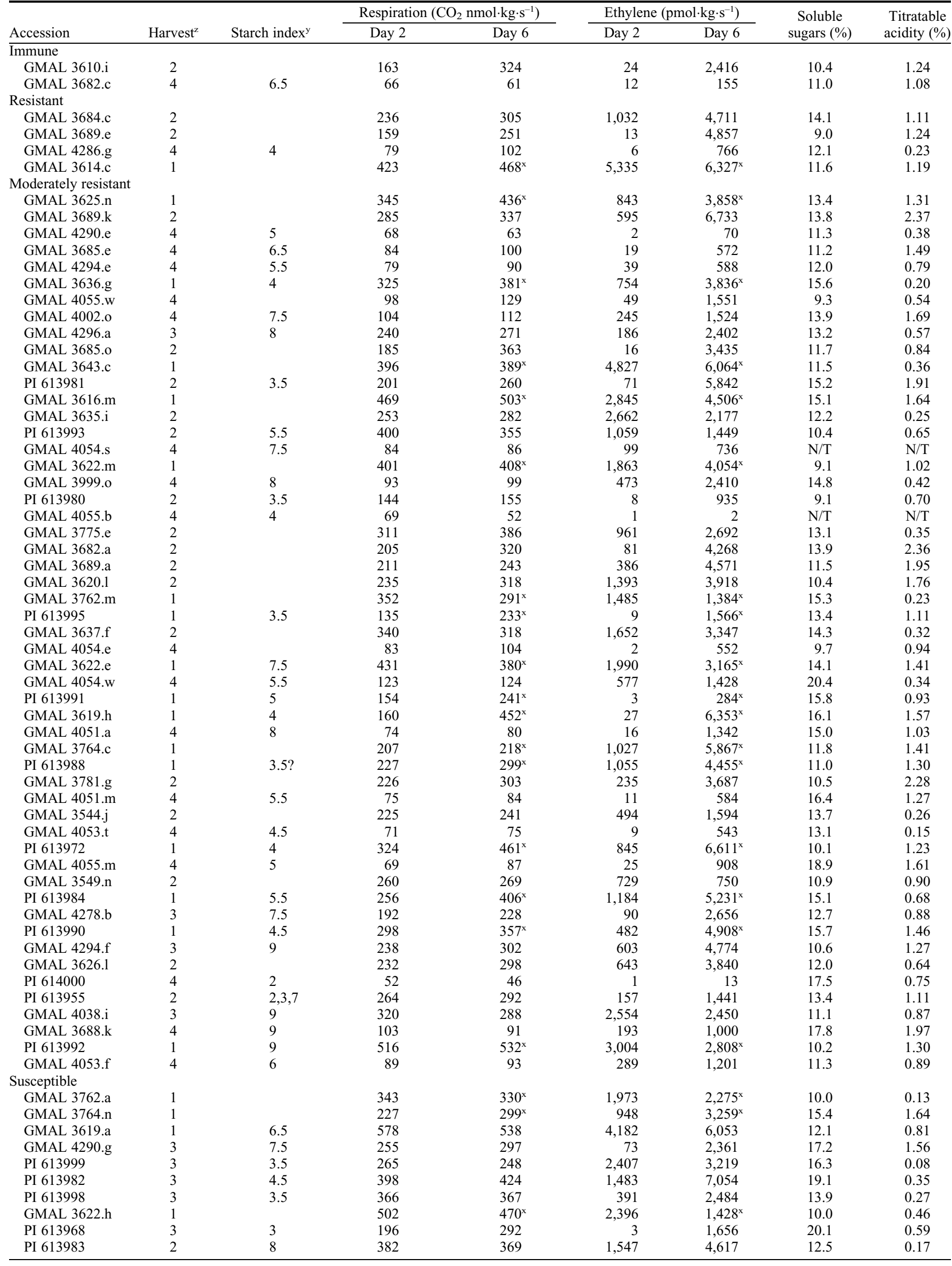

(Continued on next page) 
Table 2. (Continued) Maturity or quality indices of apples from the Kazak collection Elite (PI) and seedlings (GMAL) evaluated for susceptibility to blue mold.

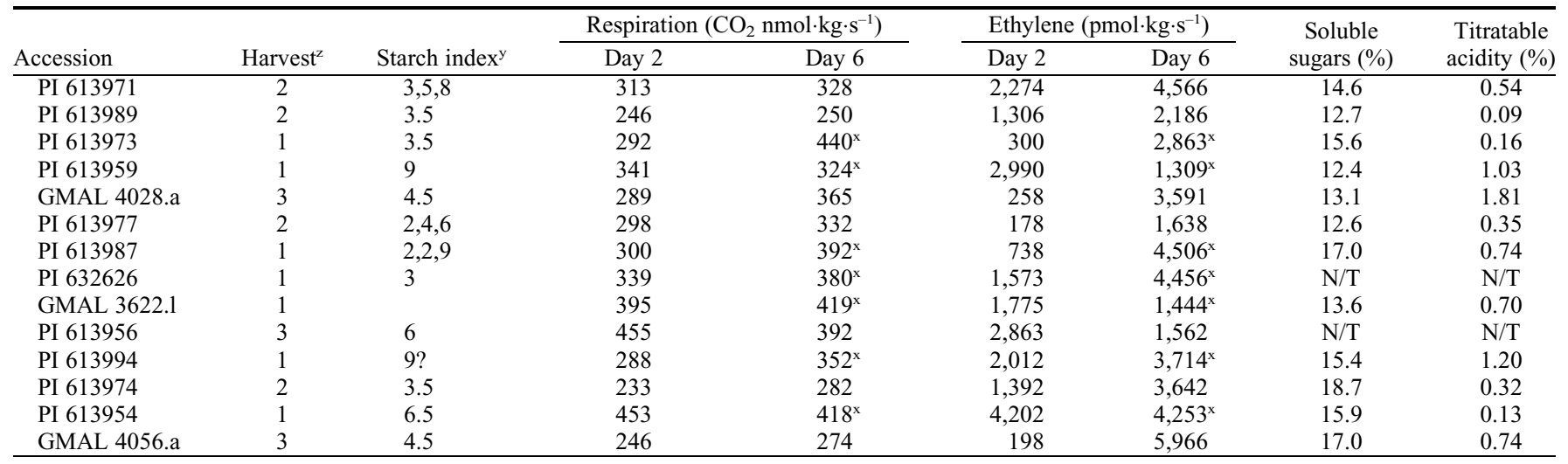

${ }^{2}$ Date of harvest: $1=8-9$ Aug., $2=21-22$ Aug., $3=7$ Sept., $4=26-27$ Sept.

${ }^{y}$ Starch index for Golden Delicious, scale 1 to 9: $1=$ entire apple cross section with starch, $9=$ no starch.

${ }^{x}$ Day 5.

$\mathrm{N} / \mathrm{T}=$ not tested.

maturing apples. At $20{ }^{\circ} \mathrm{C}$, respiration rates, expressed as evolved $\mathrm{CO}_{2}$, of ripening summer and fall apples range from $\approx 195$ and 125 $\mathrm{nmol} \cdot \mathrm{kg}^{-1} \cdot \mathrm{s}^{-1}$, respectively (Gross, 2004). Ethylene production rates among genotypes are much less predictable, but summer apples generally have a more pronounced and distinct climacteric rise during ripening than fall apples. In some early maturing accessions such as GMAL 3614.c and 3619.a, respiration and ethylene production rates were more than double corresponding rates observed in early maturing cultivated apples (Table 2; Gross, 2004). Late maturing apples from the Kazak collection generally had respiration and ethylene production rates similar to cultivated fall apple varieties, but a few (e.g., GMAL 3682.c and PI 614000) had rates even lower than those typically found in fall apple varieties.

Two quality indices are SS and TA, which is a measure of total soluble acids. As apple fruit mature, SS rises through starch hydrolysis and the acid content declines through respiratory metabolism. In general, neither SS nor TA was correlated with respiration and ethylene production maturity indices, probably because SS and TA can be influenced greatly by orchard factors. Therefore, SS and TA are generally considered fruit quality indices and not maturity indices, although SS and TA are sometimes used in individual orchards to estimate harvest windows. Among apple accessions from the Kazak collection, SS ranged from 9.0 to 20.4 and TA from 0.2 to 2.4 (Table 2). As quality indices, the SS range of Kazak apple accessions was essentially the same as that for cultivated apples, but the TA range was broader, with some Kazak apple accessions having up to twice the acidity of two of the more acidic (e.g., 'Granny Smith', 'GoldRush') cultivated apple varieties (Corrigan et al., 1997; Lau, 1985, Miller et al., 2004). High-acidity apples may not be acceptable in the marketplace unless suitably balanced with a high SS content. Among Kazak apple accessions as with domesticated apples, respiration and ethylene production rates were the only suitable maturity indices.
Correlations between decay and maturity. Analysis of the combined data from Elite and seedling collections (83 accessions) revealed a positive correlation $(\mathrm{r}=0.92,0.86$, and 0.91 ) between decay severity and all pathogen inoculum levels, indicating consistency of the decay data for the accessions at all pathogen inoculum levels (Table 3). A similar relationship occurred for the incidence of decay, and although the correlation coefficients were smaller $(r=0.62,0.39$, and 0.72$)$, they were still high enough to indicate a correlation of practical importance. Severity of decay at $10^{3}, 10^{4}$, and $10^{5} \mathrm{~mL}^{-1}$ inoculation levels correlated best with the incidence of decay at the $1 \times 10^{3} \mathrm{~mL}^{-1}$ inoculum level $(\mathrm{r}=$ $0.82,0.80$, and 0.72 , respectively) and then declined as inoculum concentration for incidence of decay increased. This indicates consistency of decay severity results and a strong association with decay incidence, particularly at the lowest inoculum level. There are some correlations in Table 3 such as SS and Ethylene Day 6, which are statistically significant but the practical importance of which are unknown.

Decay severity was positively correlated with ethylene production at the beginning (day $2 ; r=0.25$ to 0.30 ) as well as respiration rate at the beginning ( $\mathrm{r}=0.34$ to 0.38$)$ and the end (day $6 ; r=0.26$ to 0.32 ) of the tests at all inoculum levels. However, the correlations were weak indicating (as expected) that factors other than fruit maturity were strongly influencing decay development. Also, respiration rate at the beginning $(r=0.28)$ and the end $(r=0.25)$ of the test correlated with incidence of decay but only at the lowest inoculum level. Thus, as apples matured and ripened, lesion size increased at all inoculum levels, but an increase in incidence of decay was apparent only at the lowest inoculum level. Ethylene correlated well with the respiration rate at the beginning $(r=0.76)$ and the end $(r=0.66)$ of the test, indicating that both of these maturity indices were similarly reporting the physiological maturity of the fruit.

Soluble solids were rather weakly correlated with decay severity ( $r=0.36$ to 0.42$)$ at all inoculum levels and with decay incidence $(\mathrm{r}=0.36)$ at the $1 \times 10^{3} \mathrm{~mL}^{-1}$ inoculum level. This supports the general belief that high sugar content contributes moderately to the susceptibility of fruit to decay. Titratable acidity was negatively correlated with decay severity ( $\mathrm{r}=-0.23$ to -0.28$)$ but not incidence at all inoculum levels. Because TA generally decreases during apple maturation and ripening (Biale and Young, 1981), the inverse correlations between TA and decay support the general observation that less mature apples are more resistant to decay. Titratable acidity also was negatively correlated, albeit not significantly, with ethylene production and respiration at the beginning of the test. This is consistent with the general pattern of less mature apples containing more TA and lower respiration and ethylene production rates than more mature fruit. More correlations occurred between decay severity and fruit maturity and quality indices than between incidence of decay and fruit maturity and quality indices. This suggests that severity of decay would be the preferred measure in determining how fruit maturity affects apple resistance to $P$. expansum.

\section{Conclusions}

Our results indicate a great diversity among the accessions in the Kazak apple collection not only in susceptibility to decay, but also in maturation patterns. The domestication of the apple is likely to have imposed a genetic bottleneck in that only a small fraction of the wild germplasm was selected to become a part of the domestic crop. Genetic bottlenecks can cause a myriad number of potential problems from vulnerability to a new or more virulent pathogen to a lack of genetic variation to make genetic improvements. The Kazak apple collection appears to have a greater genetic diversity than cultivated apples as evidenced by its broad range of fruit maturity, quality, and disease resistance patterns and eventually should serve as a potential source of genetic material to improve postharvest fruit resistance against $P$. expansum. This research is ongoing to further determine the level of 
Table 3. Pearson's correlation coefficients for data means from the Kazak collection. ${ }^{\mathrm{z}}$

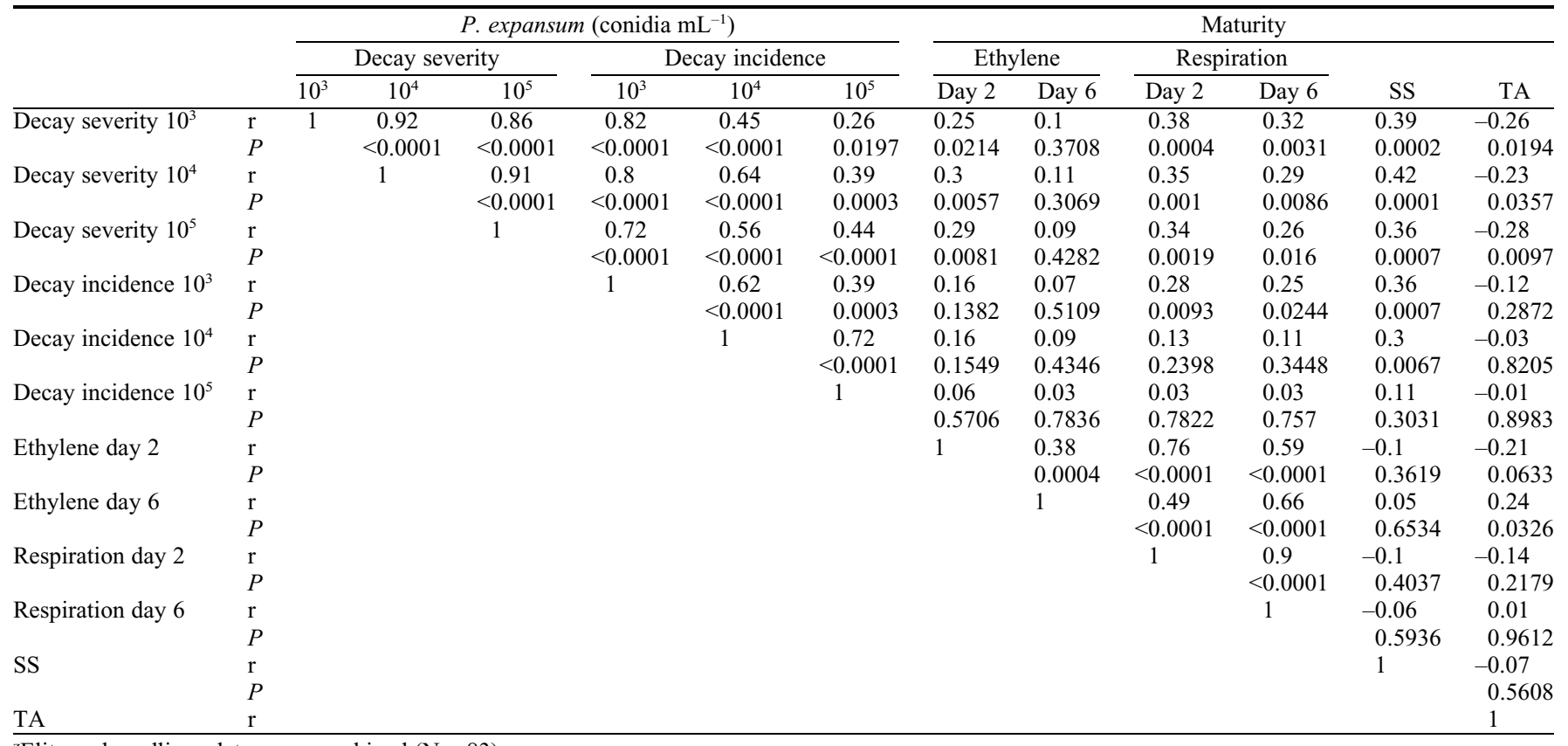

${ }^{2}$ Elite and seedlings data were combined $(\mathrm{N}=83)$.

$\mathrm{SS}=$ soluble solids; TA $=$ titratable acidity.

resistance of accessions categorized as immune, resistant, and moderately resistant (best 20 accessions) and to test additional accessions that were not included in the current study because of the lack of fruit resulting from a strong biannual fruiting pattern of the trees in the Kazak collection.

\section{Literature Cited}

Baile, J.B. and R.E. Young. 1981. Respiration and ripening in fruits-retrospect and prospect. In: Friend, J. and M.J.C. Rhodes (eds.). Recent advances in the biochemistry of fruits and vegetables. Acad. Press, New York.

Cappellini, R.A., M.J. Ceponis, and G.W. Lightner. 1987. Disorders in apple and pear shipments to the New York market, 1972-1984. Plant Dis. 71:852-856.

Corrigan, V.K., P.L. Hurst, and G.B. Boulton. 1997. Sensory characteristics and consumer evaluations of 'Pink Lady' and other late-season apples. N. Z. J. Crop Hort. Sci. 25:375-383.

Dzhangaliev, A.D. 2003. The wild apple tree of Kazakhstan. Hort. Rev. (Amer. Soc. Hort. Sci.) 29:263-303.

Forsline, P.L., H.S. Adwinckle, E.E. Dickson, J.J. Luby, and S.C. Hokanson. 2003. Collection, maintenance, characterization, and utilization of wild apples of Central Asia. Hort. Rev. (Amer. Soc. Hort. Sci.) 29:1-61.

Gross, K.C. 2004. Summary of respiration and ethylene production rates. $10 \mathrm{Dec} .2006<\mathrm{http}: / /$ www.ba.ars.usda.gov/hb66/010respiration.pdf/>

Gullino, M.L. and L.A.M. Kuijpers. 1994. Social and political implications of managing plant diseases with restricted fungicides in Europe. Annu. Rev. Phytopathol. 32:559-579.

Hogmire, H.W. 1995. Mid-Atlantic orchard monitor guide. Northeast Reg. Agr. Eng. Serv. NRAES-75.

Izumi, H., A.E. Watada, and W. Douglas. 1996. Optimum $\mathrm{O}_{2}$ and $\mathrm{CO}_{2}$ atmospheres for storing broccoli florets at various temperatures. J. Amer. Soc. Hort. Sci. 121:127-131.

Janick, J., J.N. Cummins, S.K. Brown, and M. Hemmat. 1996. Apples. In: Janick, J. and J.N.
Moore (eds.). Fruit breeding, Volume I: Tree and tropical fruits. John Wiley \& Sons, New York. Janisiewicz, W.J. and L. Korsten. 2002. Biological control of postharvest diseases of fruits. Annu. Rev. Phytopathol. 40:411-441.

Janisiewicz, W.J., B. Leverentz, W.S. Conway, R.A. Saftner, A.N. Reed, and M.J. Camp. 2003. Control of bitter rot and blue mold of apples by integrating heat and antagonist treatments on 1-MCP treated fruit stored under controlled atmosphere conditions. Postharvest Biol. Technol. 29:129-143.

Janisiewicz, W.J. and A. Marchi. 1992. Control of storage rots on various pear cultivars with a saprophytic strain of Pseudomonas syringae. Plant Dis. 76:555-560.

Janisiewicz, W.J. and D.L. Peterson. 2004. Susceptibility of stem pull area of mechanically harvested apples to blue mold decay and its control with a biocontrol agent. Plant Dis. 88:662-664.

Kader, A.A. 1985. Biochemical and physiological basis for effects of controlled and modified atmospheres on fruits and vegetables. Food Technol. 40:99-104.

Kelman, A. 1984. Opportunities for future research in postharvest pathology, p. 76-80. In: Moline, H.E. (ed.). Postharvest pathology of fruits and vegetables: Postharvest losses in perishable crops. Agr. Expt. Sta. Bulletin 1914, Berkeley, CA.

Lau, O.L. 1985. Harvest guide for B.C. apples. British Columbia Horticulturists 7:1A-20A.

Lennox, C.L. and R.A. Spotts. 2003. Sensitivity of populations of Botrytis cinerea from pear-related sources to benzimidazole and dicarboximide fungicides. Plant Dis. 87:645-649.

Lurie, S. 1998. Postharvest heat treatments of horticultural crops. Hort. Rev. 22:91-121.

Miller, S., R. McNew, R. Belding, L. Berkett, S. Brown, J. Clements, J. Cline, W. Cowgill, R. Crassweller, E. Garcia, D. Greene, G. Greene, C. Hampson, L. Merwin, R. Moran, T. Roper, J. Schupp, and E. Stover. 2004. Performance of apple cultivars in the 1995 NE-183 regional project planting: II. Fruit quality characteristics. J. Amer. Pomol. Soc. 58:65-77.
Mitcham, B and A. Kader 1996. Methods for determining quality of fresh commodities. Univ. Calif. Perishable Handling Nwslt. 85.

Mitcham E.J., C.H. Crisosto, and A.A. Kader. 2007. Apple: 'Golden Delicious'. 2 Oct. 2007. <http://postharvest.ucdavis.edu/Produce/ ProduceFacts/Fruit/golden.shtml/>.

Narayanasamy, P. 2006. Postharvest pathogens and disease management. J. Wiley \& Sons, Inc., Hoboken, NJ.

Ragsdale, N.N. and H.D. Sisler. 1994. Social and political implications of managing plant diseases with decreased availability of fungicides in the United States. Annu. Rev. Phytopathol. 32:545-557.

Rosenberger, D. 1999. Cleaning storages and apple bins to minimize postharvest decay problems. Scaffolds Fruit Journal (Cornell UniversityAgricultural Station, Geneva, NY) Vol. 8, No. 17.

Saftner, R.A., J.A. Abbott, W.S. Conway, and C.L. Barden. 2003. Effects of 1-methylcyclopropene and heat treatments on ripening and postharvest decay in 'Golden Delicious' apples. J. Amer. Soc. Hort. Sci. 128:120-127.

Saltveit, M.E. 2004. Respiratory metabolism. 10 Dec. 2006. <http://www.ba.ars.usda.gov/hb66/ 019respiration.pdf/>.

Smith, R.B., E.C. Lougheed, E.W. Franklin, and I. McMillan. 1979. The starch-iodine test for determining stage of maturation in apples. Can. J. Plant Sci. 59:725-735.

Spotts, R.A., L.A. Cervantes, and E.A. Mielke. 1999. Variability in postharvest decay among apple cultivars. Plant Dis. 83:1051-1054.

Vavilov, N.I. 1927. Geographic regularity in distribution of genes of cultivated plants. Trans. Appl. Bot. Gen. Breed. 17:100-101.

Vavilov, N.I. 1930. Five continents. Trans. by Doris Love. (1997). IPGRI/VIR, Rome, Italy.

Watkins, C.B., E. Kupferman, and D.A. Rosenberger. 2004. Apple. 10 Dec. 2006. <http:// www.ba.ars.usda.gov/hb66/027apple.pdf/>.

Wilson, C.L., A. El Ghaouth, E. Chalutz, S. Droby, C. Stevens, J.Y. Lu, V. Khan, and J. Arul. 1994. Potential of induced resistance to control postharvest diseases of fruits and vegetables. Plant Dis. 78:837-843. 